\title{
Estimation of the Optimal Periods for Planting and Felling Larix kaempferi Based on the Period of Its Cambial Activity ${ }^{1}$
}

\author{
Hye-Ji $\mathrm{YOO}^{2} \cdot$ Jeong-Deuk $\mathrm{JU}^{3} \cdot \mathrm{Jun}-\mathrm{Hui} \mathrm{PARK}^{4} \cdot$ Chang-Seob $\mathrm{SHIN}^{3} \cdot$ \\ Chang-Deuk $\mathrm{EOM}^{5} \cdot$ Jeong-Wook SEO $\mathbb{D}^{6, \dagger}$
}

\begin{abstract}
This study was conducted to suggest the optimal periods for planting and felling Larix kaempferi tree by monitoring its cambial activity period. In addition, the heat summation to induce the cambial activity of Larix kaempferi was investigated. The study sites were at Mt. Worak and Mt. Midong. After selecting 5 trees at Mt. Worak and Mt. Midong, the cambium samples were collected using a mini trephor with $2 \mathrm{~mm}$ diameter from April 7 to October 6, 2017 at Mt. Worak, and from April 7 to September 29, 2017 at Mt. Midong. After the collected cambium samples were embedded in PEG2000, transverse thin sections with a thickness of 10 to $15 \mu \mathrm{m}$ were prepared using a microtome. One Larix kaempferi sample from each site, Mt. Worak and Mt. Midong, in which the accurate monitoring of cambial activity was impossible due to the formation of traumatic resin canal, was excluded from the study. The observation of the initiation date of cambial activity under a light microscopy revealed that 2 specimens from Mt. Worak and 3 from Mt. Midong showed the initiation on April 28. The remaining 2 specimens of Mt. Worak and 1 specimen of Mt. Midong were initiated on May 4, which was a week later than the others. The heat summation that induced the initiation of cambial activity was 196.4-271.8 at Mt. Worak and 204.7-277.3 at Mt. Midong, which was similar. The termination of cambial activity occurred between August 4 and 25 at Mt. Worak, and between August 4 and September 1 at Mt. Midong. Based on the above results, it was found that the optimal planting period for Larix kaempferi in Mt. Worak and Mt. Midong was before April, about a month before the cambium activity, and the felling period was from October when the cambial activity was completely terminated.
\end{abstract}

Keywords: Larix kaempferi, planting, felling, cambial activity, degree-days, Mt. Midong, Mt. Worak

\section{INTRODUCTION}

Larix kaempferi (Lamb.) Carrière was first in- troduced to Korea in 1904 for reforestation and wood utilization (National Institute of Forest Science, 2019). However, the domestic forests were greatly damaged

\footnotetext{
${ }^{1}$ Date Received May 5, 2021, Date Accepted July 9, 2021

2 Department of Forest Products, College of Agriculture, Life and Environment Science, Chungbuk National University, Chungju 28644, Republic of Korea

${ }^{3}$ Department of Forest Science, College of Agriculture, Life and Environment Science, Chungbuk National University, Chungju 28644, Republic of Korea

${ }^{4}$ National Park Research Institute, Korea National Park service, Wonju 26441, Korea

${ }^{5}$ Division of Wood Industry, Department of Forest Products and Industry, National Institute of Forest Science, Seoul 02455, Republic of Korea

${ }^{6}$ Department of Wood \& Paper Science, College of Agriculture, Life and Environment Science, Chungbuk National University, Chungju 28644, Republic of Korea

† Corresponding author: Jeong-Wook SEO (e-mail: jwseo@chungbuk.ac.kr, ORCID: 0000-0002-4395-0570)
} 
Hye-Ji YOO $\cdot$ Jeong-Deuk JU • Jun-Hui PARK $\cdot$ Chang-Seob SHIN $\cdot$ Chang-Deuk EOM $\cdot$ Jeong-Wook SEO

during the Japanese colonial period and the Korean War and have been devastated significantly due to the abusive logging and frequent disasters. The first 10-year forest reforestation plan was established in 1973 for the reforestation of destroyed forests (Korea Forest Service, 2013). Since 1975, afforestation has been carried out to secure a supply of fuel for forestry in rural areas and to restore devastated mountain areas, by designating March $21-$ April 20 every year as the national planting period (National Archives of Korea, 1974). Efforts have also been made to protect forests by strongly controlling illegal logging. The 10 -year forest reforestation plan, which initially had been planned until 1983, was successfully achieved in 1978 at the reforestation of 108 ha, which was more than the reforestation goal of 100 ha, four years earlier than the plan. At that time, the government planted fast growing trees: Populus tomentiglandulosa and Populus euramericana, and trees for wood use: Pinus koraiensis, Cryptomeria japonica, Chamaecyparis obtusa, and Larix kaempferi, etc. (Korea Forest Service, 2013). Larix kaempferi is still recommended as a planting species for economic forestry and it is a species planted nationwide except for the southern coastal region (National Institute of Forest Science, 2019). According to a 2020 survey, the area of Larix kaempferi trees planted in Korea by 2019 was 4,559 ha, which is the second most planted species following cypress (4.952 ha) (Korea Forest Service, 2020).

Larix kaempferi has a high value as a commercial purpose and is the second largest supply following pine tree. It has excellent water resistance and durability, and the price of lumber is relatively cheap, so it is widely used for building materials, ships, raw wood, plywood agricultural tools, pulp, and pellets (Kim et al., 2015; Lee et al., 2018; National Institute of Forest Science, 2019). In the case of pellets, Larix kaempferi is also a representative tree species that can be continuously supplied if it is used as a raw material for them (Kang et al., 2018; Yang et al., 2018a, 2018b). Recently, studies related to drying, heat treatment, and bending performance, etc. have been reported to increase the utilization of Larix kaempferi wood as a building material (Kim et al., 2018; Park et al., 2018; Lee, 2020; Park et al., 2020).

The suitable planting period for Larix kaempferi recommended by Korea Forest Service is between March 11 and April 30 in considering physiological characteristics and seasonal conditions (Korea Forest Service, 2000). This is because the condition right before the bud as the frozen ground during the winter melts is a suitable condition for planting. On the other hand, the recommended optimal felling period is from November in the current year to February in the following year when the growth stops. This is because, if felling is carried out in spring or summer when the moisture content in the wood is high, it is easily damaged by fungi or pests, so that the value of the wood decreases and drying occurs easily (Viitanen, 1997; Rydell et al., 2005; Brischke and Rapp, 2008). After all, the growth period of trees provides important basic data for determining the planting and felling time. The initiation and termination of radial growth of trees are determined by cambial activity, and the timing varies depending on the tree species and growing region (Deslauriers et al., 2003; Gričar et al., 2005; Rossi et al., 2006; Seo et al., 2007; Liang et al., 2009; Oberhuber and Gruber, 2010; Rathgeber et al., 2011; Seo et al., 2011). For this reason, many studies on monitoring of the period of cambial activity, which is important data to decide the timing of reforestation and felling, by tree species and region were fulfilled, however, the study on the domestic studies is not sufficint (Park and Seo, 2000; Kwon and Kim, 2005; Park et al., 2015; Seo et al., 2017). The study on the cambial activity of Larix kaempferi, which is a major planted species in Korea, has been published only one time so far (Park and Seo, 2000). 
Estimation of the Optimal Periods for Planting and Felling Larix kaempferi Based on the Period of Its Cambial Activity

The radial growth of trees occurs when secondary xylem and secondary phloem are formed by proliferation of cambial initial cells, xylem mother cells, and phloem mother cells constituting the cambial zone (hereafter, cambium) (Bhat et al., 2001; Plomion et al., 2001; Wodzicki, 2001). Secondary xylem is formed through the enlargement, thickness, and lignification processes of the cells divided from cambial initial cells and xylem mother cells (Wilson, 1970; Denne and Dodd, 1981; Malik, 2020). The timing of precipitation is an important factor influencing the initiation and termination of cambial activity in tropical or subtropical regions with distinct dry and raining seasons, (Bullock, 1997; Borchert, 1999; Dié et al., 2012), but the temperature is known as an important factor inducing the initiation of cambial activity in the temperate and cold regions with four distinct seasons (Deslauriers et al., 2008; Gričar et al., 2007; Rossi et al., 2006; Seo et al., 2007; Thibeault-martel et al., 2008). In some studies, the effect of temperature on the initiation of cambial activity was investigated using the heat summation (degree-days or heat sum) rather than the daily temperature condition (Sarvas, 1972; Seo et al., 2008; Seo et al., 2017).

Domestically, the systemic research on the monitoring of cambial activity was started with Larix kaempferi, Pinus rigida, Pinus densiflora in the Mt. Worak in Chungcheongbuk-do (Park and Seo, 2000). After that, the monitoring results of cambial activity for Pinus densiflora, Pinus koraiensis, Quercus mongolica, Robinia pseudoacacia, Cornus controversa, and Prunus sargentii in Chuncheon area were compared each other, depending on tree species (Kwon and Kim, 2005). The cambial activity of Pinus koraiensis and Chamaecyparis pisifera in Mt. Worak was analyzed as well (Seo et al., 2017). A comparative study on the period of cambial activity depending on regions was also conducted using Pinus densiflora in Anmyeon-do, Taean-gun, and Sogwang-ri, Uljin-gun (Park et al., 2015). Recently, the cambial activity of the major conifers (Abies koreana, Pinus koraiensis, Taxus cuspidata, and Picea jezoensis) distributed in the sub-alpine zone of Deogyusan National Park was monitored and the results were compared based on the tree species (Park et al., 2021). However, studies on the same species in different regions on the cambial activity have been insufficiently compared.

The present study was conducted to monitor the cambial activity of Larix kaempferi growing in different regions in Chungcheongbuk-do (hereafter Chungbuk) to establish basic data necessary to determine the optimal planting and felling period for each region. Also, the relationship between temperature and the initiation of cambial activity was investigated to elucidate how the predicted temperature change in the future can affect the change in the growth initiation of Larix kaempferi.

\section{MATERIALS and METHODS}

\subsection{Research site and tree species}

Larix kaempferi forest units planted in Chungbuk National University Academic Forest (128 $05^{\prime} 50^{\prime \prime}$ E, $\left.36^{\circ} 50^{\prime} 12^{\prime \prime} \mathrm{N}\right)$ (Mt. Worak; hereafter WRLK)

Table 1. Descriptions of experimental trees (Larix kaempferi)

\begin{tabular}{cccc}
\hline Site & Sample ID & $\begin{array}{c}\text { Diameter at breast } \\
\text { height }(\mathrm{cm})\end{array}$ & $\begin{array}{c}\text { Height } \\
(\mathrm{m})\end{array}$ \\
\hline \hline & WRLK 01 & 29.0 & 21 \\
& WRLK 02 & 34.9 & 23 \\
Mt. Worak & WRLK 03 & 29.2 & 20 \\
& WRLK 04 & 37.0 & 24 \\
& WRLK 05 & 46.8 & 24 \\
\hline \multirow{5}{*}{ Mt. Midong } & MDLK 01 & 43.0 & 21 \\
& MDLK 02 & 41.0 & 21 \\
& MDLK 04 & 44.0 & 23 \\
& MDLK 05 & 44.0 & 21 \\
\hline
\end{tabular}


Hye-Ji YOO $\cdot$ Jeong-Deuk JU $\cdot$ Jun-Hui PARK $\cdot$ Chang-Seob SHIN $\cdot$ Chang-Deuk EOM $\cdot$ Jeong-Wook SEO

Deoksan-myeon, Jecheon-si, Chungcheongbuk-do, and Chungcheongbuk-do Forest Environment Research Institute $\left(178^{\circ} 40^{\prime} 21^{\prime \prime}\right.$ E, $\left.36^{\circ} 37^{\prime} 34^{\prime \prime} \mathrm{N}\right)$ (Mt. Midong; hereafter MDLK) located in Miwon-myeon, Cheongju-si, Chungcheongbuk-do were selected as research sites (Table 1).

According to the meteorological data from the Jecheon meteorological station closest to the Mt. Worak research site, the average annual temperature for the last 45 years $(1973-2017)$ was $10.2^{\circ} \mathrm{C}$, and the annual precipitation was $1335.2 \mathrm{~mm}$ (Fig. 1). The temperatures of the coldest month (January) and the warmest month (August) were $-5.2^{\circ} \mathrm{C}$ and $23.8^{\circ} \mathrm{C}$, respectively.

The meteorological data from Boeun Meteorological Center closest to the Mt. Midong research site reported that the average annual temperature for the last 45 years $(1973-2017)$ was $10.9^{\circ} \mathrm{C}$, and the annual pre- cipitation was $1276.2 \mathrm{~mm}$ (Fig. 2). Similar to data from the Jecheon meteorological station, the coldest month and the warmest month were January $\left(-3.5^{\circ} \mathrm{C}\right)$ and August $\left(24.1^{\circ} \mathrm{C}\right)$, respectively. The precipitation was the lowest in January with $25.1 \mathrm{~mm}$ and the highest in July with $308.9 \mathrm{~mm}$.

Five dominant tree in Larix kaempferi stand at each research site were selected for cambium monitoring. The method, generally used in the cambium monitoring research, was applied to this study (Rossi et al., 2006; Gruber et al., 2009; Park et al., 2021). The average diameter at breast height of the Larix kaempferi at Mt. Worak was $35.2( \pm 7.3) \mathrm{cm}$, which was smaller than the average diameter at Mt. Midong, but the average tree height at Mt. Worak was $22.4( \pm 1.8) \mathrm{m}$, slightly higher than the average tree height of 21.4 $( \pm 0.9) \mathrm{m}$ at Mt. Midong (Table 1).
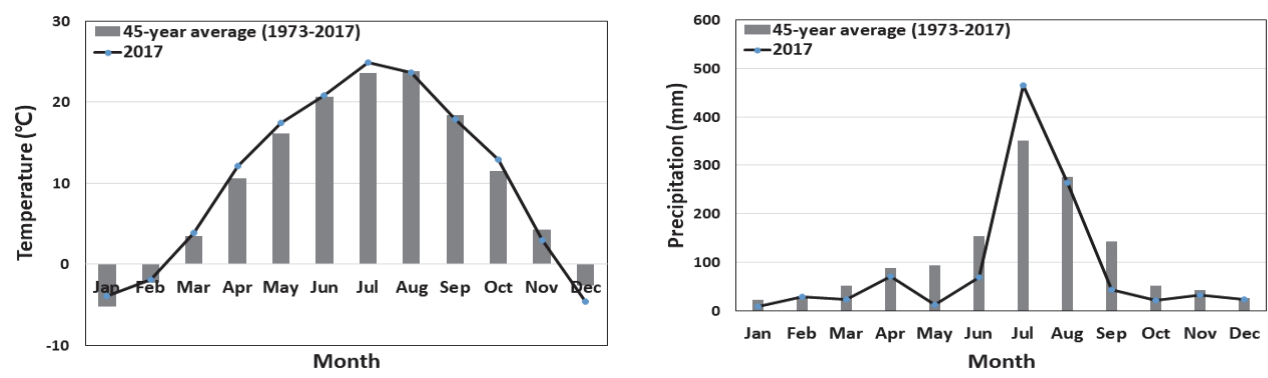

Fig. 1. Comparisons of monthly mean temperature and precipitation for 45 years (1973-2017) measured at the Jecheon meteorological station (bars) with the monthly mean temperature and precipitation in 2017 (lines).
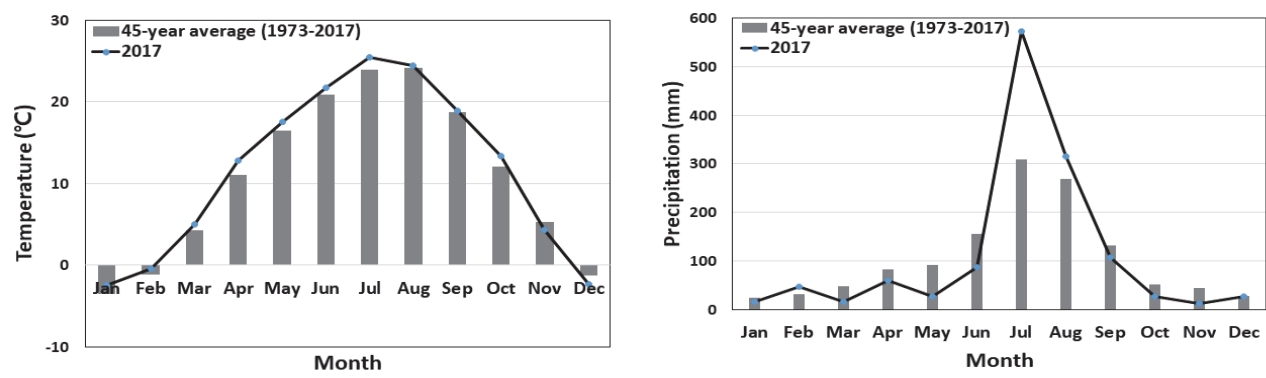

Fig. 2. Comparisons of monthly mean temperature and precipitation for 45 years $(1973-2017)$ measured at the Boeun meteorological station (bars) with the monthly mean temperature and precipitation in 2017 (lines). 


\subsection{Heat summation}

Heat summation was utilized to analyze the role of temperature in inducing the initiation of cambial activity. The heat summation was calculated by accumulating the temperature on days when the average daily temperature was higher than or equal to $5^{\circ} \mathrm{C}$, which tree growth is possible, as shown below (Sarvas, 1972; Seo et al., 2008; Seo et al., 2017). In the case of Mt. Worak, there was no available data on the temperature measured at the research site, so data from the Jecheon meteorological site were used, and for Mt. Midong, temperature data measured on site (HOBO) were used.

$$
\begin{aligned}
d . d . & =\sum_{i=j}^{365}\left(T_{\text {Diff }}\right) i \\
T_{\text {Diff }} & = \begin{cases}T_{i}-5 \text { for } T_{i}>5 \\
0 & \text { otherwise }\end{cases}
\end{aligned}
$$

Where $d . d$ is cumulated value of $T_{D i f f}, T_{D i f f}$ is the difference between the average temperature of the $i$ th Julian day and $+5^{\circ} \mathrm{C}, i$ is the Julian day on which the average daily temperature first became to be higher than $+5^{\circ} \mathrm{C}$ and lasted for 5 days or more in that condition.

\subsection{Sample preparation and observation under a light microscopy}

\subsubsection{Sample collection}

Samples were collected using a mini trephor with

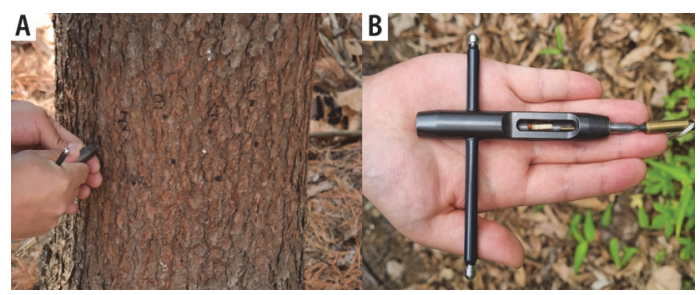

Fig. 3. Micro-sampling (A) using a trephor (B) repeated two-times in weekly intervals.
$1.9 \mathrm{~mm}$ diameter, so that the cambium and at least two recent tree rings of the secondary xylem were included (Fig. 3(A), 3(B)). Sample collection was started on April 7, 2017, at Mt. Worak and Mt. Midong, and the cambium samples was collected at weekly intervals until the day that collection ended. The last sampling dates were October 6 at Mt. Worak, and September 29 at Mt. Midong. The collected samples were stored in distilled water at the same time as they were extracted from the trees, and refrigerated until embedding to prevent drying of the samples.

\subsubsection{Embedding and preparing transverse thin section}

The transverse thin sections of the small specimen of cambium were prepared to observe the chronological cambial activities and the secondary xylem development by the season. Before embedding, the cross-sections of the small specimens were labeled with a pencil to facilitate the observation of the cross-section (Fig. 4(A)). Then, after the cambium small specimens were

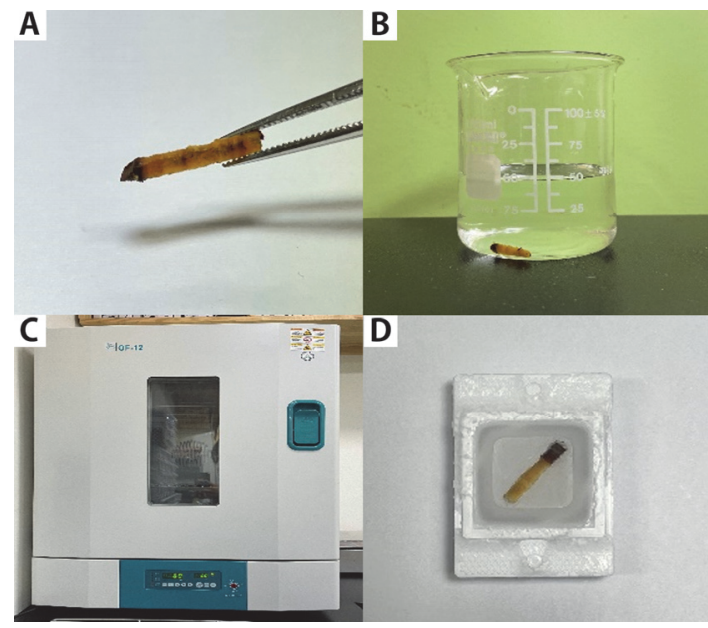

Fig. 4. The embedding process. A: marking on the cross section of micro-core with a pencil, B: the micro-core put in $25 \%$ polyethylene glycol solution, $\mathrm{C}$ : beaker placed in thermo-hygrostat set to $60^{\circ} \mathrm{C}$ for 2 or 3 days and D: embedding the micro-core in pure PEG2000. 
immersed in a mixture of distilled water and polyethylene glycol (PEG2000) at 1:3 ratio (Fig. 4(B)), they were placed in a thermo-hygrostat $(\mathrm{OF}-12 \mathrm{G}$, Jeiotech, Korea) set at $60^{\circ} \mathrm{C}$ for 2 to 3 days, so that PEG2000 slowly penetrated into the cell lumen of the small specimen as distilled water evaporated (Fig. 4(C)). The small specimens of cambium prepared as above procedures were fixed in the embedding frame using 100\% PEG2000 (Fig. 4(D)). When fixing, the small specimen pieces were placed for their cross-section to be oriented vertically.

The thin slices of the embedded samples were prepared using a sliding microtome (H/I sliding microtome, Hacker, U.S.A) with a thickness of $10-15 \mu \mathrm{m}$ (Fig. 5(A)). The thin sections were stained with a mixture of safranine $(1 \%)$ and astra blue $(0.5 \%)$ for about

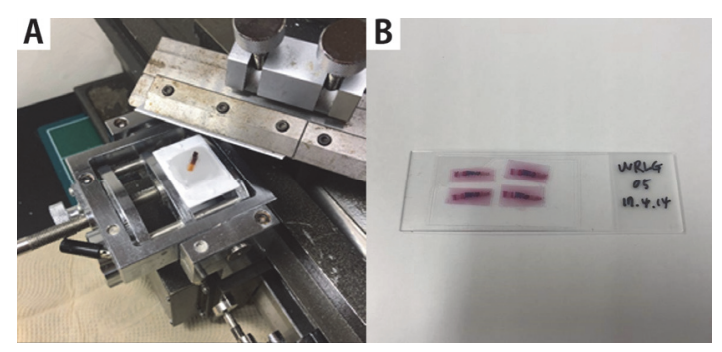

Fig. 5. Cutting a cambial sample using a sliding microtome (A) and transverse thin sections of cambium (B).
1 minute to help the observation of the cambium and the secondary xylem development. Safranine stains all xylem cell walls in red, while astra blue stains the xylem cell wall without lignin deposition in blue, which helps to observe the degree of cell development (Gärtner and Schweingruber, 2013). The stained sections were washed and sealed with cover glasses using glycerin (Fig. 5(B)).

\subsubsection{Observation of the cambium and the secondary xylem cells}

An optical microscope (Eclipse 80i, Nikon, Japan) connected with a camera (Nikon, TH/D5500 15-55VR II KIT) was used to observe the wood cells. In this study, the initiation period for cambial activity was defined as when the enlargement of the secondary xylem cells ( $\mathrm{X}_{\mathrm{E}}$ in Fig. 6(A)) divided from cambial zone ( $\mathrm{CZ}$ in Fig. 6) is exhibited. The termination of cambial activity was defined as when no further secondary xylem cell division occurred in the cambium (Fig. 6(C)).

\section{RESULTS and DISCUSSION}

Accurate monitoring of cambial activity was impossible in one specimen of Larix kaempferi from each site, Mt. Worak (WRLK05) and Mt. Midong (MDLK05),

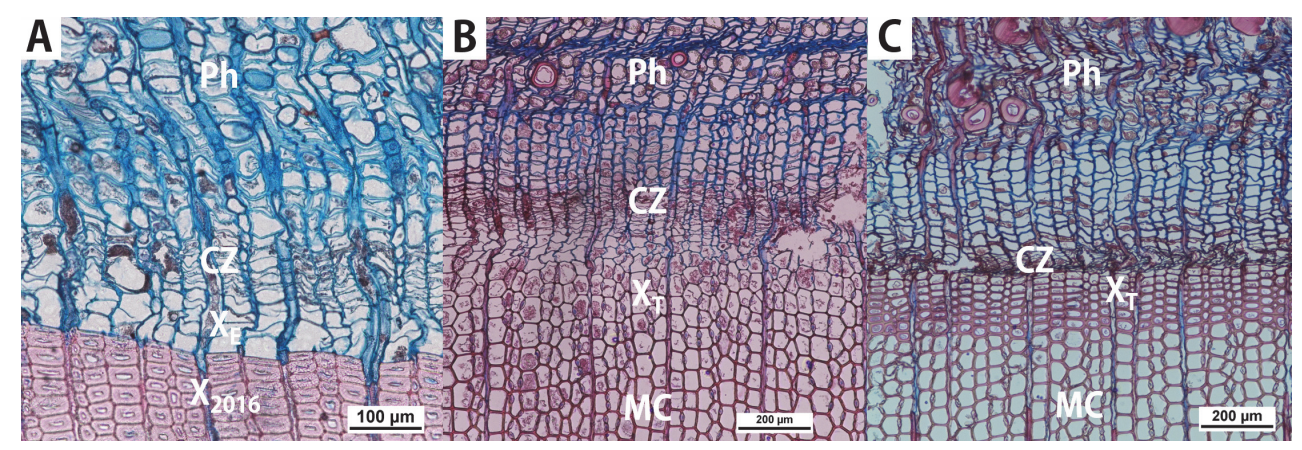

Fig. 6. Transverse thin sections. A: The beginning of cell division in the cambial zone on the $28^{\text {th }}$ of April, B: cell development on the $2^{\text {nd }}$ of June, C: the cessation of the cell division on the $3^{\text {rd }}$ of July in 2017 (Ph: phloem, CZ: cambial zone, $\mathrm{X}_{\mathrm{E}}$ : xylem cells at the enlargement, $\mathrm{X}_{\mathrm{T}}$ : xylem cells at the cell wall thickness, $\mathrm{X}_{2016}$ : xylem cells formed in 2016 and MC: mature cells). 
Estimation of the Optimal Periods for Planting and Felling Larix kaempferi Based on the Period of Its Cambial Activity

because a traumatic resin canal was observed. For this reason, each of the 4 specimens in which the normal cambial activity and the secondary xylem cell development process were confirmed, was used in the further analysis of the results.

\subsection{The initiation of cambial activity and accumulated temperature}

Two out of four specimens of Larix kaempferi from Mt. Worak (WRLK 02 and WRLK 03) and 3 out of 4 specimens from Mt. Midong (MDLK 02, MDLK 03, and MDLK 04) showed the initiation of cambial activity on April $28^{\text {th }}$. The remaining 2 Larix kaempferi samples from Mt. Worak (WRLK 01, WRLK 04) and the remaining 1 sample from Mt. Midong (MDLK 01) showed the initiation on May 4, a week later than the others. Therefore, it was observed that the cambial activity of Larix kaempferi at Mt. Worak and Mt. Midong started between late April - early May (Fig. 7). Accumulated temperature till April 28 at Mt. Worak and Mt. Midong was 196.4 and 204.7, respectively, and heat summation till May 4 was 271.8 and 277.3, respectively, showing no significant difference (Fig. 7).

According to the previous monitoring results of cambial activity surveyed at Mt. Worak, the initiation of cambial activity of Larix kaempferi, Pinus densiflora, and Pinus rigida was confirmed to be in mid April, late April, and early May, respectively (Park and Seo, 2000), and that of Pinus koraiensis and Chamaecyparis pisifera was confirmed to be in mid April, and late April (Seo et al., 2017). It was confirmed that the initiation period of Larix kaempferi determined by the current study was similar to Pinus
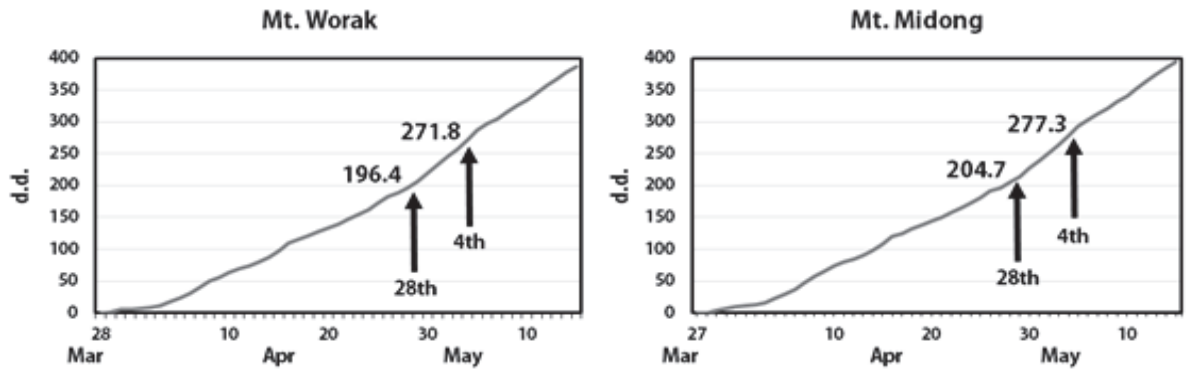

Fig. 7. Degree-days (d.d.) of Larix kaempferi at Mt. Worak (left) and Mt. Midong (right) to induce the cambial activity.

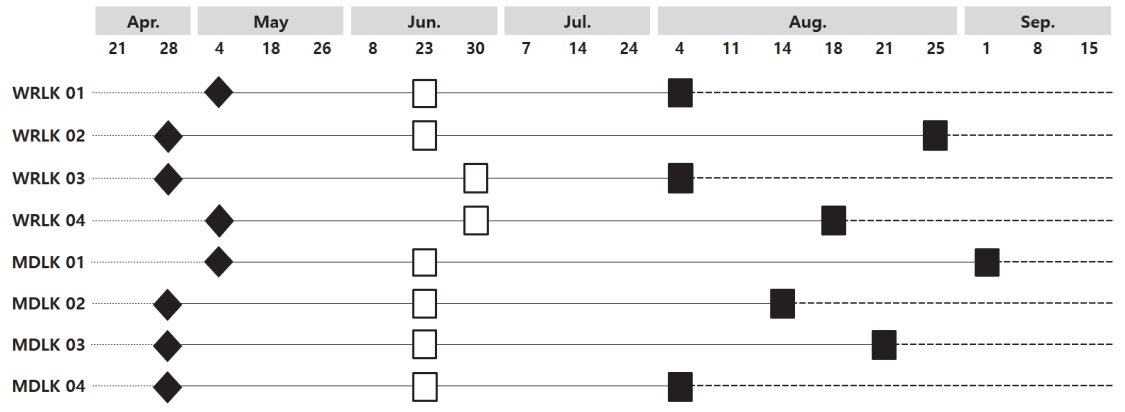

Fig. 8. Durations of wood formation by cambial activity for WRLK (Larix kaempferi at Mt. Worak) and MDLK (Larix kaempferi at Mt. Midong). ( $\bullet$ : beginning of cambial activity $\square$ : beginning of latewood formation - : end of cambial activity). 
Hye-Ji YOO $\cdot$ Jeong-Deuk JU $\cdot$ Jun-Hui PARK $\cdot$ Chang-Seob SHIN $\cdot$ Chang-Deuk EOM $\cdot$ Jeong-Wook SEO

densiflora, Pinus rigida, and Chamaecyparis pisifera, and later than the results for Larix kaempferi and Pinus koraiensis in the previous study. Because the climate is different each year, the comparison of the dates of cambial activity initiation investigated in different years does not reflect the climatic conditions of the current year. However, because an important influencing factor to induce the initiation of cambial activity is the temperature (Deslauriers et al., 2008; Gričar et al., 2007; Rossi et al., 2006; Seo et al., 2007; Thibeault-martel et al., 2008), the utilization of accumulated temperature could allow for the comparison with other species in the same area. Among the studies conducted at Mt. Worak, there have been cases in which the accumulated temperature was applied to the investigation of the initiation of cambial activity in Pinus koraiensis and Chamaecyparis pisifera (Seo et al., 2017). According to this study, the initiation of cambial activity of Pinus koraiensis and Chamaecyparis pisifera was possible when the accumulated temperature was 134 and 200, respectively. The initiation of cambial activity of Larix kaempferi of Mt. Worak determined in this study was confirmed to be possible when the accumulated temperature was 196.4, which is similar to that of Chamaecyparis pisifera. In the case of Larix kaempferi at Mt. Midong, there was no study conducted in the same area, so comparative analysis was not possible. However, since the results were confirmed to be similar to those of Larix kaempferi at Mt. Worak, it is expected that the confirmed results can be applied in the same way.

Unlike Mt. Midong, the weather station used to calculate the accumulated temperature of Mt. Worak is about $30 \mathrm{~km}$ away from the site, and a slight difference from the temperature of the site should be expected. Temperature measurements for accurate calculation of accumulated temperature in Mt. Worak area should be considered in future research.

\subsection{Initiation and termination period of cambial activity}

The termination of cambial activity for Larix kaempferi at Mt. Worak was started on August 4 (WRLK 01 and WRLK 03) and observed on August 18 (WRLK 04) and 25 (WRLK 02) (Fig. 8). The termination of cambial activity was confirmed on August 4 (MDLK 04) for Larix kaempferi at Mt. Midong as well, but unlike Mt. Worak, the cambial activity was terminated one by one at weekly intervals, and it was confirmed that the cambium activity was completely terminated by September 1 (MDLK 01). Therefore, the termination period of cambial activity was found to be somewhat later in Larix kaempferi at Mt. Midong compared to Mt. Worak. As a result of calculating the difference between results in this study and previous investigation on the initiation period of cambial activity, the cambium activity period of the Larix kaempferi of Mt. Worak was 104.75 days (93-120 days), which was 5 days shorter than 111.25 days (99-121 days) of Larix kaempferi of Mt. Midong.

The terminations of cambial activity of Pinus koraiensis and Chamaecyparis pisifera at Mt. Worak occurred from September 15 to 22 and from August 18 to September 22, respectively (Seo et al., 2017). This is 2 weeks later for Chamaecyparis pisifera and 6 weeks later for Pinus koraiensis than on August 4, which was confirmed as the earliest day of the termination of cambial activity in the present study. For the period of cambial activity, that of Larix kaempferi was confirmed as more then 40 days shorter than Pinus koraiensis (157 days) and Chamaecyparis pisifera (145-147 days) (Seo et al,. 2017). Thus, the cambial activity period for Larix kaempferi was significantly shorter than those of Pinus koraiensis and Chamaecyparis pisifera, and the main reason was considered that its termination of cambial activity occurred earlier than other species. This was investigated to be similar to Mt. Midong, which is about $50 \mathrm{~km}$ away from Mt. Worak. 


\subsection{Planting and felling period for Larix kaempferi}

It was reported that the optimal planting time taking into account of the physiological activity of trees is just before the bud break (Korea Forest Service, 2000, 2013). According to a previous study on Pinus sylvestris, its cambial activity was found to occur $2-5$ weeks after the bud break (Seo et al., 2011). If the time of the bud break for Larix kaempferi at Mt. Worak and Mt. Midong would be estimated based on the results of this previous study, it can be predicted to be after late March to mid April, about 2-5 weeks earlier than April 28, when its cambial activity was confirmed. Therefore, it was considered that the appropriate time for planting Larix kaempferi trees in the Chungbuk area, where this study sites are located, would be from March 11, following the recommendations of the Korea Forest Service. However, no later than end of March is desirable, when the earliest tree activity is expected.

Generally, the recommended optimal period for felling is from November in the current year to February in the following year when the growth stops. (Viitanen, 1997; Rydell et al., 2005; Brischke and Rapp, 2008). It is to minimize the moisture content in trees and damage from fungi or pests after felling, and to increase the efficiency of drying. In considering the cambial activity period of domestic conifers investigated so far, it was confirmed that the already known felling period was well applied to conifers. However, unlike other conifers, Larix kaempferi in Mt. Worak and Mt. Midong areas were found to complete all cambial activity in early September, so it was reasoned that the optimal period for felling is from October.

\section{CONCLUSION}

It was confirmed that the cambial activity of Larix kaempferi planted in Mt. Worak and Mt. Midong start- ed from late April to early May, and the termination of cambial activity started in early August and ended in early September. Based on these results, it is desirable to complete the planting of Larix kaempferi in the Chungbuk region before April, and it was considered that possible felling period is from October to the resting period of the following year. Through this study, the heat summation affecting the initiation of the cambial activity of Larix kaempferi in Mt. Worak and Mt. Midong was suggested, but further long term monitoring would be necessary to obtain more reliable results. Especially, an additional study will be required to find the reason that the significantly earlier termination of cambial activity in Larix kaempferi than that in other conifers (Pinus koraiensis and Chamaecyparis pisifera) confirmed in Mt. Worak is from the characteristics of the species or the from the climate conditions.

\section{REFERENCES}

Bhat, K.M., Priya, P.B., Rugmini, P. 2001. Characterisation of juvenile wood in teak. Wood Science and Technology 34: 517-532.

Borchert, R. 1999. Climatic periodicity, phenology, and cambium activity in tropical dry forest trees. IAWA Jounal 20(3): 239-247.

Bullock, S.H. 1997. Effects of seasonal rainfall on radial growth in two tropical tree species. International Journal Biometeorology 41: 13-16.

Brischke, C., Rapp, A.O. 2008. Influence of wood moisture content and wood temperature on fungal decay in the field: Observations in different microclimates. Wood Science Technology 42(8): 663-677.

Denn, M.P., Dodd, R.S. 1981. The environmental control of xylem differentiation. In: Barnett JR (ed) Xylem Cell Development. Tunbridge Wells, London. 
Hye-Ji YOO $\cdot$ Jeong-Deuk JU • Jun-Hui PARK $\cdot$ Chang-Seob SHIN $\cdot$ Chang-Deuk EOM • Jeong-Wook SEO

Deslauriers, A., Morin, H., Begin, Y. 2003. Cellular phenology of annual ring formation of Abies balsamea in the Quebec boreal forest (Canada). Canadian Journal of Forest Research 33(2): 190-200.

Deslauriers, A., Rossi, S., Anfodillo, T., Saracino, A. 2008. Cambial phenology, wood formation and temperature thresholds in two contrasting years at high altitude in southern Italy. Tree physiology 28(6): 863-871.

Dié, A., Kitin, P., Kouamé F.N.G., Van den Bulcke, J., Acker, J.V., Beeckman, H. 2012. Fluctuations of cambial activity in relation to precipitation result in annual rings and intra-annual growth zones of xylem and phloem in teak (Tectona grandis) in Ivory Coast. Annals of Botany 110(4): 861-873.

Gärtner, H., Schweingruber, F.H. 2013. Microscopic preparation techniques for plant stem analysis, pp. 78 . Gričar, J., Čufar, K., Oven, P., Schmitt, U. 2005. Differentiation of terminal latewood tracheids in silver fir trees during autumn. Annals of Botany 95(6): 959-965.

Gričar, J., Zupančič, M., Čufar, K., Oven, P. 2007. Regular cambial activity and xylem and phloem formation in locally heated and cooled stem portions of norway spruce. Wood Science Technology 41(6): 463-475.

Gruber, A., Wieser, G., Oberhuber, W. 2009. Interannual dynamics of stem $\mathrm{CO} 2$ efflux in relation to cambial activity and xylem development in Pinus cembra. Tree Physiology 29(5): 641-649.

Kang, S.-B., Choi, K.-S., Lee, H.-H., Han, G.-S. 2018. Analysis of emission characteristics and emission factors of carbon monoxide and nitrogen oxide emitted from wood pellet combustion in industrial wood pellet boilers supplied according to the subsidy program of Korea Forest Service. Journal of the Korean Wood Science and Technology 46(5): 597-609.

Kim, S.-H., Yang, I., Han, K.-S. 2015. Effects of sawdust moisture content and paticle size on the fuel characteristics of wood pellet fabricated with Quercus mongolica, Pinus densiflora and Larix kaempferi sawdust. Journal of the Korean Wood Science and Technology 43(6): 757-767.

Kim, C.-K., Kim, K.-M., Lee, S.-J., Park, M.-J. 2018. Change of bending properties of $2 \times 4$ larch lumber according to span length in the four point bending test. Journal of the Korean Wood Science and Technology 46(5): 486-496.

Korea Forest Service. 2000. Forest $\&$ forestry technique vol 2 creation of forest resources, pp. 176.

Korea Forest Service. 2013. The 1st-3rd basic forest plan 1973-1997, pp. 307-334.

Korea Forest Service. 2020. The 50th Statistical yearbook of forestry, pp. 224-225.

Kwon, S.-M., Kim, N.-H. 2005. Annual ring formation of major wood species growing in Chuncheon, Korea(I) - the period of cambium activity. Journal of the Korean Wood Science and Technology 33(4): 1-8.

Lee, I.-H., Park, J.-H., Song, D.-B., Hong, S.-I. 2018. longitudinal bonding strength performance evaluation of larch lumber. Journal of the Korean Wood Science and Technology 46(1): 85-92.

Lee, C.-J. 2020. Effect of Kerfing and incising pretreatments on high-temperature drying characteristics of cedar and larch boxed-heart timbers with less than $150 \mathrm{~mm}$ in cross section size. Journal of the Korean Wood Science and Technology 48(3): 345-363.

Liang, E., Eckstein, D., Shao, X. 2009. Seasonal cambial activity of relict Chinese pine at the northern limit of its natural distribution in north China exploratory results. IAWA Journal 30(4): 371-378.

Malik, R., Rossi, S., Sukumar, R. 2020. Variations in the timing of different phenological stages of cambial activity in Abies pindrow (Royle) along an elevation gradient in the north-western Himalaya. Dendrochronologia 59: 125660. 
Estimation of the Optimal Periods for Planting and Felling Larix kaempferi Based on the Period of Its Cambial Activity

National Archives of Korea. 1974. National planting plan, pp. 1044-1045.

National Institute of Forest Science. 2019. Tree improvement and establishment of breeding system in Larix kaempferi. Research Reports, Seoul, pp. 12-19.

Oberhuber, W., Gruber, A. 2010. Climate influence on intra-annual stem radial increment of Pinus sylvestris (L.) Exposed to Drought. Trees 24: 887-898.

Park, J.-H., Choi, E.-B., Park, H.-C., Lee, N.-Y., Seo, J.-W. 2021. Intra-annual dynamics of cambial and xylem phenology in subalpine conifers at Deogyusan National Park in the Republic of Korea. Journal of Wood Science 67: 22.

Park, Y.-G., Han, Y.-J., Park, J.-H., Chung, H.-W., Kim, H.-B., Yang, S.-Y., Chang, Y.-S., Yeo, H.-M. 2018. Evaluation of deterioration of Larix kaempferi wood heat-treated by superheated steam through field decay test for 12 months. Journal of the Korean Wood Science and Technology 46(5): 497-510.

Park, Y.-G., Jeon, W.-S., Yoon, S.-M., Lee, H.-M., Hwang, W.-J. 2020. Evaluation of cell-wall microstructure and anti-swelling effectiveness of heat-treated larch wood. Journal of the Korean Wood Science and Technology 48(6): 780-790.

Park, S.-Y., Eom, C.-D., Seo, J.-W. 2015. Seasonal change of cambium activity of pine trees at different growth sites. Journal of the Korean Wood Science and Technology 43(4): 411-420.

Park, W.-K., Seo, J.-W. 2000. Long-term monitoring of climatic and soil factors, and tree growths in Worak mountain using phytogram system. The Korean Journal of Quaternay Research 14(2): 101-107.

Plomion, C., Leprovost, G., Stokes, A. 2001. Wood formation in trees. Plant Physiology 127(4): 1513-1523.

Rathgeber, C.B.K., Rossi, S., Bontemps. J.-D. 2011. Cambial activity related to tree size in a mature silver-fir plantation. Annals of Botany 108(3): 429-438.
Rossi, S., Deslauriers, A., Anfodillo, T. 2006. Assesment of cambial activity and xylogenesis by microsampling tree species: An example at the alpine timberline. IAWA Journal 27(4): 383-394.

Rydell, Å., Bergström, M., Elowson, T. 2005. Mass loss and moisture dynamics of Scots pine (Pinus sylvestris L.) exposed outdoors above ground in Sweden. Holzforschung 59: 183-189.

Sarvas, R. 1972. Investigations on the annual cycle of development of forest trees. Active period. Metsäntutkimuslaitoksen Julkaisuja 76(3): 1-110.

Seo, J.-W., Eckstein, D., Schmitt, U. 2007. The pinning method: From pinning to data preparation. Dendrochronologia 25: 79-86.

Seo, J.-W., Eckstein, D., Jalkanen, R., Rickebusch, S., Schmitt, U. 2008. Estimating the onset of cambial activity in Scots pine in northern Finland by means of the heat-sum approach. Tree Physiology 28(1): 105-112.

Seo, J.-W., Eckstein, D., Jalkanen, R., Schmitt, U. 2011. Climatic control of intra- and inter-annual woodformation dynamics of Scots pine in northern Finland. Environmental and Experimental Botany 72(3): 422-431.

Seo, J.-W., Choi, E.-B., Ju, J.-D., Shin, C.-S. 2017. The Association of intra-annual cambial activities of Pinus koraiensis and chamaecyparis pisifera planted in Mt. Worak with climatic Factors. Journal of the Korean Wood Science and Technology 45(1): 43-52.

Thibeault-martel, M., Krause, C., Morin, H., Rossi, S. 2008. Cambial activity and intra-annual xylem formation in roots and stems of abies balsamea and picea mariana. Annals of botany 102(5): 667-674.

Viitanen, H.A. 1997. Modelling the time factor in the development of brown rot decay in pine and spruce sapwood - The effect of critical humidity and temperature conditions. Holzforschung 51: 99-106. 
Hye-Ji YOO $\cdot$ Jeong-Deuk JU $\cdot$ Jun-Hui PARK $\cdot$ Chang-Seob SHIN $\cdot$ Chang-Deuk EOM $\cdot$ Jeong-Wook SEO

Wilson. B.F. 1970. The Growing Tree, pp. 152.

Wodzicki, T.J. 2001. Natural factors affecting wood structure. Wood Science and Technology 35: 5-26.

Yang, I., Han, G.-S., Oh, S.-W. 2018a. Larch pellets fabricated with coffee waste and the commercializing potential of the pellets. Journal of the Korean Wood Science and Technology 46(1): 48-59.
Yang, I., Han, G.-S. 2018b. Comparison of domestic and overseas allowable standards related to emissions from wood pellet combustion. Journal of the Korean Wood Science and Technology 46(5): 553-564. 
Estimation of the Optimal Periods for Planting and Felling Larix kaempferi Based on the Period of Its Cambial Activity

\section{APPENDIX}

(Korean Version)

\section{형성층 활동 기간을 활용한 일본잎갈나무 식재 및 벌채 적기 추정}

초록 : 본 연구는 우리나라 주요 조림수종인 일본잎갈나무 형성층 활동 시기를 모니터링 하여 적절한 식재 및 벌채시기를 제시하기 위해 수행되었다. 또한, 각 지역 일본잎갈나무의 형성층 활동을 유도하는 적산온도도 함께 조사하였다. 연구지는 충청북도에 위치한 월악산과 미동산이다. 월악산과 미동산에서 일본잎갈나무 5 본씩을 선발한 후, 월악산에서는 2017년 4월 7일 10월 6일, 미동산에서는 2017년 4월 7일 9월 29일까지 직경 $2 \mathrm{~mm}$ 미니 생장추(trephor)로 형성층 시료를 채취하였다. 채취된 형성층 시료는 PEG2000에 임베딩 한 후, 마이크로톰을 이용하여 두께 $10 \sim 15 \mu \mathrm{m}$ 로 박편 제작을 하였다. 상해세포간구 발생으로 정확한 형성층 활동 모니터링이 불가능한 월악산 일본잎갈나무 1 본과 미동산 일본잎갈나무 1 본은 연구에서 제외하였 다. 현미경으로 월악산과 미동산 일본잎갈나무의 형성층 개시 일을 관찰한 결과, 4 월 28 일에 월악산에서 2 본, 미동산에서 3 본이 개시하였다. 나머지인 월악산 2 본과 미동산 1 본은 일주일 후인 5 월 4 일에 개시하였다. 형성층 활동 개시를 유도한 적산온 도는 월악산의 경우 196.4-271.8이었으며, 미동산은 204.7-277.3로 유사하였다. 형성층 활동 종료는 월악산 8월 4일 8월 25 일, 미동산 8 월 4 일 9월 1 일이었다. 이상의 결과를 근거로 월악산과 미동산에 적합한 일본잎갈나무 식재 시기는 형성층 활동 약 한 달 전인 4 월 이전이며, 벌채 시기는 형성층 활동이 완전히 종료되는 10 월부터로 확인되었다.

\section{1. 서론}

일본잎갈나무(Larix kaempferi (Lamb.) Carrière)는 산림녹화 및 목재이용을 목적으로 1904년 우리나라에 처음으로 도입되었 다(National Institute of Forest Science, 2019). 하지만 일제강점기와 한국전쟁을 겪으며 국내 산림은 크게 훼손되었으며, 남벌과 빈번한 재해로 인해 매우 황폐해졌다. 황폐한 산림녹화를 위해 1973년 제1차 치산녹화 10개년 계획을 수립하였다(Korea Forest Service, 2013). 1975년부터는 매년 3월 21일에서 4월 20일까지 국민 식수 기간으로 정하여 농촌의 임산연료 공급원 확보와 황폐산지 복구를 위해 조림을 실행하였다(National Archives of Korea, 1974). 또한 무단 벌채를 강력하게 통제하여 산림보호에 도 힘썼다. 당시 1983년까지 계획에 있던 10개년 치산녹화 계획은 4년 앞당겨진 1978년에 조림 목표인 100 ha보다 더 많은 $108 \mathrm{ha}$ 의 산림녹화를 성공하였다. 당시 정부는 속성수인 은수원사시, 이태리포플러 그리고 용재림으로 잣나무, 삼나무, 편백, 일본잎갈나무를 식재하였다(Korea Forest Service, 2013). 일본잎갈나무는 지금까지도 경제림 조성을 위한 조림수종으로 권장되 고 있으며, 남부 해안지방을 제외한 전국 각지에 식재되고 있는 수종이다(National Institute of Forest Science, 2019). 2020년에 조사된 바에 따르면 2019년까지 국내에 조림된 일본잎갈나무의 면적은 4,559 ha로 편백(4.952 ha) 다음으로 가장 많이 조림되고 있는 수종이다(Korea Forest Service, 2020).

일본잎갈나무는 용재수종으로서의 가치가 높고, 소나무 다음으로 공급량이 많은 수종이다. 내수성과 내구성이 뛰어나고 제재목 가격이 비교적 저렴하여 건축재, 선박, 생목, 합판 농업 용구, 펄프, 펠릿으로 많이 사용되고 있다(Kim et al., 2015; Lee et al., 2018; National Institute of Forest Science, 2019). 펠릿의 경우 일본잎갈나무를 원료로 사용한다면 지속적인 공급이 가능한 대표수종이기도 하다(Kang et al., 2018; Yang et al., 2018a, 2018b). 최근에는 건축용재로써의 일본잎갈나무 이용률을 높이기 위하여 건조, 열처리, 휨 성능 등과 관련된 연구들이 발표되고 있다(Kim et al., 2018; Park et al., 2018; Lee, 2020; Park et al., 2020)

산림청에서 권장하고 있는 일본잎갈나무의 식재 적기는 생리적 특성과 계절 조건을 고려하여 3 월 11 일부터 4 월 30 일까지이다 (Korea Forest Service, 2000). 겨우내 동결된 땅이 풀리면서, 수목의 눈이 트기 직전의 상태가 식재에 적합한 조건이기 때문이다. 반면, 벌채는 생장이 정지한 11 월 이후부터 이듬해 2 월을 적기로 권장하고 있다. 수목 내에 수분의 이동이 많고, 부피생장이 왕성한 봄 또는 여름에 벌채를 하게 되면 목재 내 함수율이 높아 균이나 해충의 피해를 쉽게 받아 목재의 가치가 떨어지고 건조가 쉽게 발생되기 때문이다(Viitanen, 1997; Rydell et al., 2005; Brischke and Rapp, 2008). 결국, 수목의 생장 기간은 식재 및 벌채 시기를 정하는 데 중요한 기초자료가 된다. 수목의 직경생장 개시와 종료는 형성층 활동에 의해 결정되며, 수종과 생육 지역에 따라서 그 시기가 다르다(Deslauriers et al., 2003; Gričar et al., 2005; Rossi et al., 2006; Seo et al., 2007; Liang et al., 2009; Oberhuber and Gruber, 2010; Rathgeber et al., 2011; Seo et al., 2011). 이러한 이유로 수종과 지역에 
Hye-Ji YOO $\cdot$ Jeong-Deuk JU $\cdot$ Jun-Hui PARK $\cdot$ Chang-Seob SHIN $\cdot$ Chang-Deuk EOM $\cdot$ Jeong-Wook SEO

따른 형성층 활동 시기를 파악하는 것은 조림 및 벌채시기를 결정하는데 중요한 자료임에도 불구하고 국내의 관련 연구는 부족한 실정이다(Park and Seo, 2000; Kwon and Kim, 2005; Park et al., 2015; Seo et al., 2017). 특히, 국내 주요 조림 수종인 일본잎갈나무에 관한 연구는 현재까지 한편 발표되었다(Park and Seo, 2000).

수목의 직경생장은 형성층대(이하 형성층)를 구성하고 있는 시원세포, 목부모세포, 사부모세포의 분열에 의해 2차 목부와 2차 사부가 만들어지면서 이루어진다(Bhat et al., 2001; Plomion et al., 2001; Wodzicki, 2001). 2차 목부는 시원세포와 목부모 세포에서 분열된 세포가 확대, 비후, 목질화 과정을 거쳐 생성된다(Wilson, 1970; Denne and Dodd, 1981; Malik, 2020). 건기와 우기가 뚜렷한 열대 또는 아열대 지역에서는 강수 발생 시기가 형성층 활동 개시와 종료에 중요한 영향 인자이지만(Bullock, 1997; Borchert, 1999; Dié et al., 2012), 4계절이 뚜렷한 온대 및 한대 지역에서는 온도가 형성층 활동 개시를 유도하는 데 중요 인자로 알려져 있다(Deslauriers et al., 2008; Gričar et al., 2007; Rossi et al., 2006; Seo et al., 2007; Thibeault-martel et al., 2008). 일부 연구에서는 일일 온도조건 보다 적산온도(degree-days or heat sum)라는 누적된 온도를 활용하여 온도가 형성층 활동 개시에 미치는 영향을 조사하였다(Sarvas, 1972; Seo et al., 2008; Seo et al., 2017).

국내에서 형성층 활동 모니터링에 관한 체계적인 연구는 충북 월악산 일본잎갈나무(Larix leptolepis: Larix kaempferi 이명), 리기다소나무(Pinus rigida), 소나무(Pinus densiflora)를 대상으로 시작되었다(Park and Seo, 2000). 이후 수종에 따른 형성층 활동 시기 비교를 위해 춘천지역 소나무(Pinus densiflora), 잣나무(Pinus koraiensis), 신갈나무(Quercus mongolica), 아까시나 무(Robinia pseudoacacia), 층층나무(Cornus controversa), 산벚나무(Prunus sargentii) 형성층 모니터링 결과가 상호 비교되었 으며(Kwon and Kim, 2005), 월악산 잣나무(Pinus koraiensis)와 화백(Chamaecyparis pisifera) 형성층 모니터링 결과도 상호 비교 분석되었다(Seo et al., 2017). 지역에 따른 형성층 활동 시기 비교 연구도 태안군 안면도와 울진군 소광리 소나무(Pinus densiflora)를 대상으로 조사되었다(Park et al., 2015). 최근에는 덕유산국립공원 아고산대에 분포하고 있는 주요 침엽수 구상나 무(Abies koreana), 잣나무(Pinus koraiensis), 주목(Taxus cuspidata), 가문비나무(Picea jezoensis)의 형성층 활동을 모니터링하 여 수종 상호 간 차이를 비교하였다(Park et al., 2021). 동일 지역에서 여러 수종을 대상으로 한 연구에 비하여 다른 지역에 있는 동일 수종을 대상으로 형성층 활동을 비교 분석한 연구는 부족하여 관련된 연구가 요구되고 있다.

본 연구는 충청북도(이하 충북) 내 다른 지역에서 생육 중인 일본잎갈나무(Larix kaempferi)의 형성층 활동을 모니터링하여 지역에 따른 적합한 식재 및 벌채 시기 결정에 필요한 기초자료를 마련하기 위해 수행되었다. 또한 향후 예측되는 온도 변화가 일본잎갈나무 생육 개시 변화에 어떠한 영향을 주는지를 밝히기 위해 온도와 형성층 활동 개시와의 관계도 함께 조사하였다.

\section{2. 재료 및 방법}

2.1. 연구지 개황 및 수종 선정

충북 제천시 덕산면에 위치한 월악산 내의 충북대학교 학술림 $\left(128^{\circ} 05^{\prime} 50^{\prime \prime} \mathrm{E}, 36^{\circ} 50^{\prime} 12^{\prime \prime} \mathrm{N}\right)($ 이하 월악산, WRLK)과 충북 청주 시 미원면에 위치한 충청북도 산림환경연구소(178 $\left.40^{\prime} 21^{\prime \prime} \mathrm{E}, 36^{\circ} 37^{\prime} 34^{\prime \prime} \mathrm{N}\right)($ 이하 미동산, MDLK)에서 식재된 일본잎갈나무 임분 을 연구지로 선정하였다(Table 1).

월악산 연구지와 가장 인접한 제천 측후소 기상자료에 따르면 최근 45 년(1973-2017년) 간 연평균기온은 $10.2^{\circ} \mathrm{C}$ 이며, 연강수 량은 $1335.2 \mathrm{~mm}$ 이었다(Fig. 1) 최한월인 1 월과 최난월인 8 월의 온도는 각각 $-5.2^{\circ} \mathrm{C}$ 와 $23.8^{\circ} \mathrm{C}$ 이었으며, 강수량이 가장 적은 달인 1 월과 가장 많은 달인 7월의 강수량은 각각 $23.1 \mathrm{~mm}$ 와 $350.5 \mathrm{~mm}$ 이었다.

미동산 연구지와 가장 인접한 보은 측후소에서 측정한 최근 45 년(1973-2017년)간 연평균기온은 $10.9^{\circ} \mathrm{C}$ 이었으며, 연강수량은 $1276.2 \mathrm{~mm}$ 이었다(Fig. 2). 제천측후소 자료와 마찬가지로 최한월과 최난월은 각각 1 월 $\left(-3.5^{\circ} \mathrm{C}\right)$ 과 8 월 $\left(24.1^{\circ} \mathrm{C}\right)$ 이었다. 강수량은 1월에 $25.1 \mathrm{~mm}$ 로 가장 적었으며, 7월에 $308.9 \mathrm{~mm}$ 로 가장 많았다.

형성층 모니터링을 위해 각 지역 일본잎갈나무 임분에서 우세목을 대상으로 5 본씩을 선발하였다. 형성층 모니터링 연구에서 5 본을 활용하는 방법이 일반적으로 적용되고 있어, 이 방법을 본 연구에 적용하였다(Rossi et al., 2006; Gruber et al., 2009; Park et al., 2021). 월악산 일본잎갈나무의 평균 흥고직경은 $35.2( \pm 7.3) \mathrm{cm}$ 으로 미동산 일본잎갈나무의 평균 흥고직경인 $41.7( \pm 3.2) \mathrm{cm}$ 보다 작았으나, 평균 수고는 22.4( \pm 1.8$) \mathrm{m}$ 로 미동산 일본잎갈나무의 평균 수고인 21.4( \pm 0.9$) \mathrm{m}$ 보다 소폭 컸다 (Table 1).

\section{2. 적산온도}

형성층 활동 개시를 유도한 온도의 역할을 분석하기 위하여 적산온도를 활용하였다. 적산온도는 일평균기온이 수목생장이 가능한 $5^{\circ} \mathrm{C}$ 이상인 날의 온도를 아래의 식과 같이 누적하여 계산하였다(Sarvas, 1972; Seo et al., 2008; Seo et al., 2017). 
월악산의 경우 연구지를 대상으로 측정된 온도 자료가 없어 제천 측후소에 자료를 활용하였으며, 미동산은 현장에서 측정 (HOBO)한 기온 자료를 활용하였다.

$$
\begin{aligned}
& d . d=\sum_{i=j}^{365}\left(T_{\text {Diff }}\right) i \\
& T_{\text {Diff }}= \begin{cases}T_{i}-5 \text { for } T_{i}>5 \\
0 & \text { otherwise }\end{cases}
\end{aligned}
$$

여기서 $d . d$ 는 $T_{D i f f}$ 의 누적값, $T_{D i f f}$ 는 $i$ 번째 율리우스 일의 평균온도와 $+5^{\circ} \mathrm{C}$ 차이, $i$ 는 일평균기온이 처음으로 $+5^{\circ} \mathrm{C}$ 이상 5 일 이상 지속된 기간이 시작되는 율리우스 일이다.

\section{3. 시료 준비 및 현미경 관찰}

2.3.1. 시료 채취

직경 $1.9 \mathrm{~mm}$ 미니 생장추(trephor)를 이용하여 형성층과 2 차 목부의 최근 나이테가 두 개 이상 포함되도록 시료를 채취하였다 (Fig. 3(A), 3(B)). 시료 채취 개시는 월악산과 미동산 모두 2017년 4월 7일이며, 종료일까지 일주일 간격으로 형성층 채취를 실시하였다. 월악산에서의 시료 채취 종료일은 10 월 6 일이며, 미동산은 9 월 29 일이었다. 현장에서 채취된 시료의 건조를 방지하 기 위해 수집과 동시에 증류수에 담아 보관하였으며, 임베딩 전까지 냉장보관을 하였다.

\subsection{2. 임베딩(embedding) 및 박편제작}

계절에 따른 형성층 및 2 차 목부 세포 발달 활동 관찰을 위해 형성층 소시험편의 횡단면(cross-section)을 대상으로 박편을 제작하였다. 임베딩 전 소시험편의 횡단면 관찰이 용이하도록 소시험편의 횡단면에 연필로 표시하였다(Fig. 4(A)). 다음으로 증류수와 polyethylene glycol (PEG2000)을 1:3 비율로 혼합한 용액에 형성층 소시험편을 침지 시킨 후(Fig. 4(B)), 증류수가 증발되면서 PEG2000이 소시험편의 세포내강에 천천히 침투하도록 $60^{\circ} \mathrm{C}$ 로 맞춘 항온 항습기(OF-12G, Jeiotech, Korea)에 2 3일 넣어두었다(Fig. 4(C)). 이상의 과정이 완료된 형성층 소시험편은 $100 \% \mathrm{PEG} 2000$ 을 이용하여 임베딩 틀에 고정하였다 (Fig. 4(D)). 고정 시 소시험편의 횡단면이 상하에 위치하도록 하였다.

임베딩이 완료된 시료의 박편은 활주식 마이크로톰(H/I sliding microtome, Hacker, U.S.A)을 이용하여 제작하였으며, 박편의 두께는 10-15 $\mu \mathrm{m}$ 가 되도록 하였다(Fig. 5(A)). 다음으로 형성층 및 2차 목부 발달 정도를 관찰하기 위해 제작된 박편을 safranine (1\%)과 astra blue $(0.5 \%)$ 로 혼합한 혼합용액으로 약 1 분간 염색하였다. Safranine은 모든 목부 세포벽을 붉은색으로 염색시키는 반면, astrablue는 리그닌이 침착되지 않은 목부 세포벽 부분을 파란색으로 염색시키므로 세포 발달 정도를 관찰하는 데에 도움이 된다(Gärtner and Schweingruber, 2013). 염색이 완료된 박편은 세척 후 glycerin을 사용하여 커버 글라스(cover glass)로 봉입하였다(Fig. 5(B)).

\subsection{3. 형성층 및 2 차 목부세포 관찰}

세포 관찰을 위해 카메라(Nikon, TH/D5500 15-55VR II KIT)가 연결되어 있는 광학현미경(Eclipse 80i, Nikon, Japan)을 사용하였다. 본 연구에서 형성층 활동 개시는 형성층대(CZ in Fig. 6)에서 분열된 2차 목부세포의 확대( $\mathrm{X}_{\mathrm{E}}$ in Fig. 6(A))가 관찰되는 때로 정의하였다. 형성층 활동 종료는 형성층대에서 더 이상의 2 차 목부 세포 분열이 일어나지 않고, 가장 최근에 생성된 2차 목부 세포에서 목질화가 관찰되었을 때로 정의하였다(Fig. 6(C)).

\section{3. 결과 및 고찰}

월악산(WRLK05)과 미동산(MDLK05)에서 1본씩의 일본잎갈나무에서 상해세포간구(traumatic resin canal)가 관찰되어 정 확한 형성층 활동 모니터링이 불가능하였다. 이러한 이유로 각 지역에서 정상적인 형성층 활동과 2 차 목부세포 발달 과정이 확인되는 4 본씩 이용하여 결과 분석에 활용하였다.

\section{1. 형성층 활동 개시와 적산온도}

월악산 일본잎갈나무 4 본 중 2 본(WRLK 02, WRLK 03)과 미동산 일본잎갈나무 4본 중 3 본(MDLK 02, MDLK 03, MDLK 04)은 4월 28일에 형성층 활동이 개시되었다. 이를 제외한 월악산 일본잎갈나무 2 본(WRLK 01, WRLK 04)과 미동산 일본잎갈 
Hye-Ji YOO $\cdot$ Jeong-Deuk JU • Jun-Hui PARK $\cdot$ Chang-Seob SHIN $\cdot$ Chang-Deuk EOM • Jeong-Wook SEO

나무 1본(MDLK 01)은 일주일 후인 5월 4일에 개시가 관찰되었다. 따라서 월악산과 미동산 일본잎갈나무의 형성층 활동은 모두 4월 말-5월 초에 개시하는 것으로 조사되었다(Fig. 7). 4월 28일까지 월악산과 미동산의 적산온도는 각각 196.4와 204.7이 었으며, 5월 4일까지 적산온도는 각각 271.8와 277.3으로 큰 차이가 없는 것으로 조사되었다(Fig. 7).

과거 월악산에서 조사된 형성층 활동 모니터링 결과에 따르면 일본잎갈나무, 소나무, 리기다소나무의 형성층 활동 개시는 각각 4월 중순, 4 월 말, 5 월 초로 확인되었으며(Park and Seo, 2000), 잣나무와 화백은 각각 4월 중순과 4월 말이었다(Seo et al., 2017). 본 연구를 통해 확인된 월악산 일본잎갈나무의 형성층 활동 개시는 소나무, 리기다소나무, 화백과는 비슷하고 과거 확인된 일본잎갈나무와 잣나무보다 늦는 것으로 확인되었다. 매년 기후가 다르기 때문에 다른 해에 조사된 형성층 활동 개시 일을 상호 비교하는 것은 당년 기후조건이 반영되지 않는다. 그러나 형성층 활동 개시 유도에 중요한 영향 인자는 온도 (Deslauriers et al., 2008; Gričar et al., 2007; Rossi et al., 2006; Seo et al., 2007; Thibeault-martel et al., 2008)기 때문에, 적산온도를 활용하여 동일 지역의 다른 수종과 비교할 수 있었다. 월악산에서 수행된 연구 중 적산온도가 형성층 활동 개시 조사에 적용된 사례는 잣나무와 화백이 있다(Seo et al., 2017). 이 연구에 따르면 잣나무와 화백의 형성층 활동 개시는 적산온도 가 각각 134 와 200 일 때 가능하다. 본 연구에서 확인된 월악산 일본잎갈나무의 형성층 활동 개시는 적산온도가 196.4 일 때 가능한 것으로 확인되었으며, 이는 화백이 비슷한 적산온도이다. 미동산 일본잎갈나무의 경우 동일한 지역에서 수행된 연구가 없어 비교 분석을 할 수는 없었으나, 월악산 일본잎갈나무와 유사한 결과가 확인되어 이미 확인된 결과를 동일하게 적용 가능할 것으로 판단된다.

월악산 적산온도 계산에 사용된 측후소는 미동산과는 달리 현장에서 약 $30 \mathrm{~km}$ 떨어져 있어 현장의 온도와 다소 차이가 존재할 것이다. 월악산 지역에 대한 정확한 적산온도 계산을 위한 온도 측정은 향후 연구에서는 고려되어야 할 것이다.

\section{2. 형성층 활동 종료 및 기간}

월악산 일본잎갈나무의 형성층 활동 종료는 8월 4일(WRLK 01, WRLK 03)을 시작으로, 8월 18일(WRLK 04)과 8월 25일 (WRLK 02)에도 확인되었다(Fig. 8). 미동산 일본잎갈나무도 8월 4일(MDLK 04)일부터 형성층 활동 종료가 확인되었으나, 월악산과 달리 일주일 간격으로 한 본씩 형성층 활동이 종료되어 9월 1 일(MDLK 01)까지 형성층 활동이 종료되는 것으로 확인되었다. 따라서 미동산 일본잎갈나무는 월악산 일본잎갈나무와 비교했을 때 형성층 활동 종료 시점이 다소 늦는 것으로 조사되었다. 본 결과와 앞서 조사된 형성층 활동 개시 일과의 차이를 계산한 결과, 월악산 일본잎갈나무의 형성층 활동 기간은 104.75 일(93-120일)로 미동산 일본잎갈나무의 111.25 일(99-121일)보다 5일 짧았다.

월악산에서 조사된 잣나무의 형성층 활동 종료 시기는 9월 15일-22일이며, 화백은 8월 18일-9월 22일이었다(Seo et al., 2017). 이는 이번 연구에서 가장 이른 형성층 활동 종료일로 확인된 8 월 4 일보다 화백은 2 주, 잣나무는 6 주 늦은 것이다. 형성층 활동 기간의 경우, 일본잎갈나무는 잣나무의 약 157 일과 화백의 약 145-148일(Seo et al,. 2017)보다 약 40일 이상 짧은 것으로 확인되었다. 따라서 일본잎갈나무의 형성층 활동 기간은 잣나무와 화백에 비해 현저히 짧으며, 그 주요인은 형성층 활동 종료 시기가 다른 수종에 비해 일찍 발생되기 때문으로 판단되었다. 이는 월악산에서 약 $50 \mathrm{~km}$ 떨어진 미동산에서 유사한 것으로 조사되었다.

\section{3. 일본잎갈나무 식재 및 벌채시기}

수목의 생리적 활동을 고려한 최적의 식재 시기는 수목의 눈이 트기 직전으로 보고되어 있다(Korea Forest Service, 2000, 2013). 구주소나무(Pinus sylvestris)를 이용한 선행연구에 따르면, 구주소나무의 형성층 활동은 눈이 트기 시작한 2 5주 후에 발생하는 것으로 조사되었다(Seo et al., 2011). 이 선행연구 결과를 근거로 월악산과 미동산 일본잎갈나무의 눈이 트는 시기를 추정한다면 형성층 활동이 확인된 4월 28일보다 약 2 5주 이른 3월 말 4월 중순 이후일 것으로 예측된다. 따라서 본 연구지가 위치한 충북지역에 일본잎갈나무를 식재 시 적절한 시기는 산림청에서 권고하는 3 월 11 일부터를 따라도 될 것으로 판단되었다. 다만, 가장 이른 수목활동이 예상되는 3 월 말을 넘기지 않는 것이 바람직할 것으로 판단되었다.

일반적으로 권고되는 벌채 적기는 수목생장이 정지된 11월 이후부터 이듬해 2월이다(Viitanen, 1997; Rydell et al., 2005; Brischke and Rapp, 2008). 수목 내 함수율 및 벌채 후 균이나 해충의 피해를 최소화하고, 건조 효율을 높이기 위해서이다. 지금까지 조사된 국내 침엽수의 형성층 활동 기간을 고려해 볼 때, 이미 알려져 있는 벌채 기간은 침엽수에 잘 적용되는 것으로 확인되었다. 다만, 월악산과 미동산 지역 일본잎갈나무는 다른 침엽수들과는 다르게 9 월 초면 모든 형성층 활동이 종료되는 것으로 조사되어 벌채 적기를 10 월 이후로 적용이 가능할 것으로 판단되었다. 
Estimation of the Optimal Periods for Planting and Felling Larix kaempferi Based on the Period of Its Cambial Activity

\section{4. 결론}

월악산과 미동산에 식재된 일본잎갈나무의 형성층 활동 개시는 4월 말에서 5 월 초이며, 형성층 활동 종료는 8 월 초를 시작으로 9월 초면 모두 종료하는 것으로 확인되었다. 본 결과를 근거로 충북지역 일본잎갈나무 식재는 4월 이전에 완료하는 것이 바람직 하며, 벌채는 10 월 이후부터 이듬해 휴식기까지가 가능한 것으로 판단되었다. 본 연구를 통해 적산온도가 월악산과 미동산 일본잎갈나무 형성층 활동 개시에 영향을 주는 기준을 마련하였으나, 보다 신뢰성 있는 결과를 획득하기 위해서는 장기간의 모니터링이 수행되어야 할 것이다. 특히, 월악산에서 확인된 다른 침엽수(잣나무와 화백)의 형성층 활동 종료보다 현저히 빠른 이유가 수종의 특성인지, 기후조건에 따른 영향인지에 관한 추가 연구가 요구된다. 